\title{
Assessment of the Ability to Perform Activities of Daily Living: A Study Among Freedom Fighters in Bangladesh
}

\author{
Haider $\mathrm{SA}^{1}$, Miah $\mathrm{MT}^{2}$, Jarrin $\mathrm{R}^{3}$, Khan $\mathrm{MAI}^{4}$ \\ ${ }^{1}$ Department of Surgery, Dhaka Shishu (Children) Hospital, Dhaka, Bangladesh; ${ }^{2}$ Department of \\ Medicine, Dhaka Medical College, Dhaka, Bangladesh; ${ }^{3}$ Salimullah Road, Mohammadpur, Dhaka, \\ Bangladesh; ${ }^{4}$ Department of Respiratory Medicine, National Institute of Diseases of the Chest and \\ Hospital (NIDCH), Dhaka, Bangladesh
}

\begin{abstract}
Background: Bangladesh got its glorious victory of independence in 1971 from Pakistan after nine months of the liberation war. After 47 years, freedom fighters are in geriatric age.

Objective:The study was aimed to assess the ability to perform daily living activities among the Freedom fighters of Bangladesh.

Methods: It was a cross-sectional study and a mixed-method qualitative and quantitative. It was conducted from December 2017 to May 2018. A total of 153 freedom fighters who actively participated in the Liberation War were randomly selected from eight Bangladesh divisions. The Sami-structure questionnaire was collected in quantitative data. Qualitative data was collected by key informant interviews (KII) Physical functional status was determined by Activity of Daily Living Scales (ADLS) and Instrumental Activity of Daily Living Scales (IADLS). Freedom fighters who actively participated in the Liberation War and gladly participated were included in the study.

Results: Among the 153 respondents, $92.8 \%$ were Muslim and mean age $68.50 \pm 5.808$ years. Their monthly family income was a minimum of 6000 BDT and a maximum of 500000 BDT, and $92.2 \%$ received the freedom fighter allowance. Most of them lived with their family members and about half of them took care of themselves. Activities of the daily living scale showed that two-third of them had difficulties in one or more activities. The Instrumental Activities of daily living scale revealed that most of them had problems in one or more instrumental activities.
\end{abstract}

Conclusion: This study revealed that the ability to perform daily living activities was so difficult for Freedom fighters at their old ages. Further large-scale studies involving all living freedom fighters could show a more complex scenario.

Keywords: Freedom fighters, Daily activity, Activity of Daily Living Scales, IADLS

\section{Introduction}

In 1971 Bangladesh became an independent state from Pakistan after a nine-month-long liberation war. As per the Government selected Red Book, it was identified that $1,51,861$ persons were involved in the war actively. The whole Bengali nation feels proud of our freedom fighters. After 47 years, all freedom fighters are in the geriatric age group and eventually, all of them are not in good health. Aging is generally a process of deterioration in an individual's functional capacity that results from structural changes with the advancement of age. ${ }^{1}$ Deficit in multiple senses were strongly associated with age, gender and race. ${ }^{2}$ Falls in older adults found The deficiencies in numerous senses were strongly associated with age, gender and race and significant cause of morbidity and mortality. ${ }^{2}$ Falls was an important aspect of geriatric

*Correspondence: Dr. Shawkat Ara Haider, Department of Surgery, Dhaka Shishu (Children) Hospital, Dhaka, Bangladesh;

e-mail: haider.shadman@gmail.com; ORCID:0000-0002-9409-8533 medicine. It was closely related with daily activities. The Center for Disease Control (CDC) reported that one in five falls caused a serious injury such as a broken bone or head injury. Fear of falling can also seriously affected an aging adult's quality of life. Gait disturbances were a common medical problem in old age. In Bangladesh, people became older around the age of 60 because of poverty, and physical, hardworking, inability, and illness due to malnutrition and geographical conditions. ${ }^{3}$ Difficulty with the Activity of daily living (ADL) and difficulty with the instrumental Activity of daily living (IADL) were more common with advancing age. ${ }^{4}$

Few instruments had been developed to measure complex activities such as shopping, cooking, managing finances (also termed "instrumental activities of daily living") necessary for functioning in community settings. To assess the normal daily life activities of old people, the Activity of Daily Living Scales (ADLS)' and the 'Instrumental Activity of Daily Living Scales 
(IADLS) were used. ${ }^{5}$ The capacity to handle these complex functions normally had usually been lost before basic "activities of daily living" (e.g., eating, bathing, toileting), which A.D.L. scales could measure. ${ }^{6}$ Therefore, assessing IADLS might identify an incipient decline in older adults. In ALDs the total score ranges from 0 to 6 , and for IADLs, from 0 to 8 . In some categories, only the highest level of function received 1; in others, two or more levels had scores of 1 because each described competence representing some minimal function level. These screens were useful for indicating precisely how a person was performing now. ${ }^{7,8}$ As a progression of life, freedom fighters (F.F.s) of Bangladesh passed the old age where their daily living status had not been studied yet. Therefore, we aimed to assess the ability to perform daily living activities among Bangladesh's freedom fighters.

\section{Materials and Methods}

It was a cross-sectional study and a mixed-method qualitative and quantitative. It was conducted from December 2017 to May 2018. According to the Government-selected red book, 1,51,861 persons actively participated in the liberation war of 1971. One hundred fifty-three respondents were selected by random sampling from eight divisions in Bangladesh. Sami-structured questioner collected quantitative data and qualitative data were collected by key informative interviews (K.I.I.). Physical functional status was determined by 'Activity of Daily Living Scales (ADLS)' and 'Instrumental Activity of Daily Living Scales (IADLS).'Every respondent would be informed of the aims of the study. Verbal informed consent was obtained from every participant. Privacy and confidentiality were strictly be maintained during data collection. The study subjects' collected information was secured in a locker under the key in the study premises. Freedom Fighters who actively took part at the Liberation War 1971 (approved by Government red book.) participated in the study and severely physically and mentally sick persons were excluded. The participant would have the liberty to refuse and withdraw from the study at any time. Key informant interviews (KII) were qualitative in-depth interviews from which we were collected detailed information. It was indepth interviews with people who knew what was going on. In the key informant interviews, we collected information from a wide range of people. Here, Key informant interview (KII) was done with ten sector commanders who willingly talked about their well-known freedom fighters. All questionnaires were checked for completeness and correctness. Coding and classification were done. Data were entered, cleaned and analyzed using statistical methods SPSS. A Chi-square test was done to see the relationship

\section{Results}

Among 153 respondents, mean age $68.50 \pm 5.808$ years (minimum age 61years and maximum 94 years $) .92 .8 \%(n=142)$ of respondents were Muslim and others were Hindus. $20 \%$ of freedom fighters were graduates and $12 \%$ master's degree holders. But $5.5 \%$ had no education and $2 \%$ could do their signature only.

\begin{tabular}{lll}
\multicolumn{3}{l}{ Table I: Demographic variables among the respondents $(\mathrm{n}=153)$} \\
\hline Variable & Frequency & Percent \\
\hline Age (completed years) & & \\
$61-65$ & 54 & 35.3 \\
$66-70$ & 62 & 40.5 \\
$70+$ & 37 & 24.2 \\
Religion & & \\
Islam & 142 & 92.8 \\
Hinduism & 11 & 7.2 \\
Education Status & & \\
Masters 'degree & 19 & 12.4 \\
Graduation & 31 & 20.3 \\
Higher Secondary & 16 & 10.5 \\
Secondary & 47 & 30.4 \\
Primary & 29 & 19.0 \\
Only signature & 3 & 2.0 \\
No education & 8 & 5.5 \\
Total & $\mathbf{1 5 3}$ & $\mathbf{1 0 0}$ \\
\hline
\end{tabular}

Their minimum monthly family income was 6000 BDT and the maximum was 500000 BDT. $92.2 \%$ received the freedom fighter allowance, $96.08 \%$ lived with their family, and about $53 \%$ took care of themselves.

Table II: Social profile of the respondents $(n=153)$

\begin{tabular}{lll}
\hline \multicolumn{1}{c}{ Variable } & Frequency & Percent \\
\hline Govt. allowance & 141 & 92.2 \\
Yes & 12 & 7.8 \\
No & & \\
Living with whom & 2 & 1.31 \\
Alone & 147 & 96.08 \\
Family members & 13 & 8.5 \\
Other family members & 1 & 0.65 \\
Others & & \\
Caregiver & 81 & 52.94 \\
Self & 57 & 37.25 \\
Husband/wife & 52 & 33.99 \\
Son & 10 & 6.54 \\
Daughter & 1 & 0.65 \\
Other family members & $\mathbf{1 5 3}$ & $\mathbf{1 0 0}$ \\
Total & & \\
\hline
\end{tabular}


Activities of daily living (ADLs) were routine activities of the people, which they did every day without assistance. There were six basic ADLs: eating, bathing, getting dressed, toileting, transferring, and continence. "Instrumental activities of daily living," or IADL's were activities related to independent living. These included preparing meals, managing money, shopping for groceries or personal items, performing light or heavy housework, doing laundry, and using a telephone. For ADLs, the total score ranges from 0 to 6 , and for IADLs, from 0 to 8 . In some categories, only the highest level of function received 1; in others, two or more groups had scores of 1 , because each described competence representing some minimal level of the process.

Table III Distribution of the respondent by "Activities of Daily Living"

\begin{tabular}{ccc}
\hline Score & Frequency & Percent \\
\hline 0 & 3 & 2.0 \\
1 & 5 & 3.3 \\
2 & 12 & 7.8 \\
3 & 17 & 11.1 \\
4 & 26 & 17.0 \\
5 & 37 & 24.2 \\
6 & 53 & 34.6 \\
Total & 153 & 100.00 \\
\hline
\end{tabular}

"Activities of Daily Living" shows that, 2\% respondents got score $0,3.33 \%$ scored $1,7.8 \%$ scored 2, 11.1\% scored 3, 17.0\% scored 4, 24.2\% scored 5 and $34.6 \%$ scored 6 .

Table IV: Distribution of the respondent by "Instrumental Activities of Daily Living" IALDs

\begin{tabular}{lll}
\hline Score & Frequency & Percent \\
\hline 0 & 5 & 3.3 \\
1 & 8 & 5.2 \\
2 & 9 & 5.9 \\
3 & 15 & 9.8 \\
4 & 23 & 15.0 \\
5 & 29 & 19.0 \\
6 & 15 & 9.8 \\
7 & 22 & 14.4 \\
8 & 27 & 17.6 \\
Total & $\mathbf{1 5 3}$ & $\mathbf{1 0 0 . 0 0}$ \\
\hline
\end{tabular}

Instrumental Activities of Daily Living" (IALDs) shows that, $3.3 \%$ respondents got score $0,5.2 \%$ scored $1,5.9 \%$ scored $2,9.8 \%$ scored $3,15.0 \%$ scored 4, 19.0\% scored 5, 9.8\% scored 6, 14.4\% scored 7 and $17.6 \%$ scored 8 .
It was to be found that the $p$-value was 0.001 (Chisquare test), which was less than the level of significance 0.05 , so the null hypothesis of no association between IADLs score and respondent's age may be rejected. So that there was a relationship between IADLs score and respondent's age.

Key Informant Interview (KII): The key informant interviews were conducted with sector commanders' freedom fighters who willingly talked about their well-known freedom fighters. At these interviews, they informed about their current health status and injury during the liberation war. They also told about the torture which Pakistani Army did to the Freedom Fighters in the tortured cell.

Some Freedom fighters had joints dislocation of their upper and lower limbs, leg injury, loss of sensation in hands and legs due to torture during the liberation war. That results from impairment of daily physical Activity.

Statement- "In 1971, When I was in the prison of torture cell, I lost my hands and fingers feelings due to physical abuse. That time I was so young, I could not feel that. At present, I have been suffering from numbness and difficulty in physical Activity for the last 7-8 years."

\section{Discussion}

After 47 years, all freedom fighters were in the geriatric age group. In this study, randomly selected 153 freedom fighters from 1,51,861 freedom fighters of eight divisions. Their mean age was $68.50 \pm 5$. Difficulty with daily living activities (A.D.L.) and Instrumental Activity of daily living (IADL) was observed in a study done by the University of Chicago, Illinois. Difficulty with A.D.L. functions was more common with advancing age. ${ }^{8}$ In this study, $\mathrm{ADL}$ and IDAL were also common with advancing age. A crosssectional study was performed on Iran-Iraq war veterans with hip or hemipelvis amputations in Iran. At that study, it was found that $83.33 \%$ had limitations in at least one domain of the IADL. A.D.L. and IADL showed an intermediate to strong correlation. ${ }^{9}$ In this study, there was a relationship between IADLs score and respondent's age. The score signified that more than one-third of Freedom fighters were found good in daily living activity and others have difficulties in one or more Activity. In another study in South Florida, IADL and A.D.L. were the most sensitive assessment of older individuals' function. ${ }^{10}$ In our study, IADL and A.D.L were correlated with ages. 
Thus, the current study assessed the ability to perform daily living activities among the Freedom fighters of Bangladesh. Moreover, during the liberation war, many Freedom fighters died, and many were injured. The injury occurred in different parts of the body by grenades, shells, bullets and cannonball. Splinters pierced different body sites, and some freedom fighters had been living with splinters at their body still now. Such wartime injuries and traumas could add another portion of the burden. 'Activity of Daily Living Scales (ADLS)' and 'Instrumental Activity of Daily Living Scales (IADLS) are widely used instruments to assess daily living activities. ${ }^{10,11,12}$

\section{Conclusion}

This study revealed that Freedom fighters' daily living activities were so difficult at their old ages. It was related to their advancing of age. Further large-scale studies involving all living freedom fighters could reveal a more complete scenario.

\section{Acknowledgments}

The authors are thankful to the Bangladesh Medical Research Council (BMRC) for funding of this study. We express our cordial gratefulness to the freedom fighters who kindly provided us valuable time for this study. $\mathrm{s}$

Conflict of interest: No conflict of interest.

Funding: Bangladesh Medical Research Council (BMRC), Dhaka

Ethical Clearance: National Ethics Committee, BMRC, Dhaka

Submitted: $12^{\text {th }}$ December, 2019

Final revision received: $16^{\text {th }}$ November, 2020

Accepted: $25^{\text {th }}$ November, 2020

Published: $1^{\text {st }}$ December, 2020

\section{References}

1. Khan MN, Mondal M.N.I., Hoque N, Islam MS, and Shahiduzzaman M. A study on quality of life of elderly population in Bangladesh. American Journal of Health Research. 2014;2:152-7.

DOI: $10.11648 / j . a j h r .20140204 .18$

2. Correia C, Lopez KJ, Wroblewski KE, Huisingh-Scheetz M, Kern DW, Chen RC, Schumm LP, Dale W, McClintock MK, and Pinto JM. Global Sensory Impairment in Older Adults in the United States. Journal of the American Geriatrics Society. 2016;64:306-13. DOI: $10.1111 /$ jgs. 13955
3. Barikdar A, Ahmed T, and Lasker SP. The Situation of the Elderly in Bangladesh. Bangladesh Journal of Bioethics. 2016;7,27-363. DOI: $10.3329 /$ bioethics.v7i1.29303

4. Haque M, and Alam M. Health Problems of the Geriatric People: A Community Based Study in a Rural Area in Bangladesh. TAJ: Journal of Teachers Association. 2003; 16, 15-9. 6. DOI: $10.3329 /$ taj.v16i1.3896

5. Instrumental Activities of Daily Living Scale. Construct: Assessment of complex activities of daily living; American psychological Association.

URL:www.apa.org/pi/about/publications/caregi vers/practice-settings/assessment/tools/dailyactivities.aspx

6. Lawton MP and Brody EM. Assessment of older people: self-maintaining and instrumental activities of daily living. Gerontologist. 1969, 9:179-86.

DOI: 10.1093/geront/9.3_Part_1.179

7. Graf C. The Lawton Instrumental Activities of Daily Living Scale. Am. J. Nurs. Sci. 2008;108:53-62.

DOI: 10.1097/01. N.A.J.0000314810.46029.74

8. Finlayson M, Mallinson T, Barbosa VM. Activities of daily living (A.D.L.) and instrumental activities of daily living (IADL) items were stable over time in a longitudinal study on aging. J Clin Epidemiol. $2005 ; 58: 338-49$.

9. Kachooei AR, Ebrahimzadeh MH, Hallaj Moghadam M, et al. Disabilities and activities of daily living among veterans with old hip disarticulation and transpelvic amputation. Arch Trauma Res. 2014;3:e16003

DOI: 10.5812/atr.16003

10. Balducci L, Beghe C. The application of the principles of geriatrics to the management of the older person with cancer. Crit Rev Oncol Hematol. 2000;35:147-54.

11. Girones R, Torregrosa D, Gomez-Codina J, Maestu I, Tenias JM, Rosell R. Lung cancer chemotherapy decisions in older patients: the role of patient preference and interactions with physicians. Clin Translational Oncol. 2012; 14: 183-189. DOI: $10.1007 / \mathrm{s} 12094-012-0782-6$

12. Kim YJ, Kim JH, Park MS, Lee KW, Kim KI, Bang SM. et al. Comprehensive geriatric assessment in Korean elderly cancer patients receiving chemotherapy. J Cancer Res Clin Oncol. 2011; 137: 839-847.

DOI: $10.1007 / \mathrm{s} 00432-010-0945-1$ 
13. Luciani A, Jacobsen PB, Extermann M, Foa P, Marussi D, Overcash JA. et al. Fatigue and functional dependence in older cancer patients. Am J Clin Oncol. 2008; 31: 424-430. DOI: 10.1097/COC.0b013e31816d915f

14. Repetto L, Fratino L, Audisio RA, Venturino A, Gianni W, Vercelli M. et al. Comprehensive geriatric assessment adds information to Eastern Cooperative Oncology Group performance status in elderly cancer patients: an Italian Group for
Geriatric Oncology Study. J Clin Oncol. 2002; 20: 494-502.

DOI: $10.1200 / J C O .2002 .20 .2 .494$

15. Leskinen MR, Laatikainen TK, Tuomilehto JO, Nissinen MA, Peltonen M, Koistinen PO, et al. Trends in health status and the use of services among the 80-84-year-old Finnish war veterans during 1992 and 2004. Scand J Public Health. 2010;38:434-441.

DOI: $10.1177 / 1403494810367730$ 